\title{
ANALISIS PENGENDALIAN INTERNAL DALAM PEMBERIAN KREDIT PADA LEMBAGA PERKREDITAN DESA (LPD) DESA PAKRAMAN TULANGNYUH CABANG KLUNGKUNG
}

\author{
Sarifah \\ Jurusan Pendidikan Ekonomi, Fakultas Ekonomi \\ Universitas Pendidikan Ganesha Singaraja, \\ Indonesia
}

e-mail: ifahmuslimah817@gmail.com

\begin{abstract}
Abstrak
Penelitian ini bertujuan untuk mendeskripsikan sistem pengendalian internal pemberian kredit, kendala yang dihadapi dalam melaksanakan sistem pengendaian intern pemberian kredit, upaya untuk mengatasi kendala dalam sistem pengendalian intern pemberan kredit pada LPD Desa Tulangyuh Cabang Klungkung. Penelitian ini merupakan penelitian deskriptif kualitatif. Subjek penelitian ini adalah LPD Desa Tulangnyuh Cabang klungkung, Sedangkan objek penelitian ini adalah sistem pengendalian internal pemberian kredit, kendala dalam sistem pengendaian intern pemberian kredit dan upaya untuk mengatasi kendala dalam sistem pengendalian intern pemberan kredit. Data dikumpulkan dengan metode wawancara dan dokumentasi. Hasil penelitian ini menunjukkan bahwa (1) sistem pemberian kredit pada LPD Desa Tulangnyuh Cabang Klungkung melalui beberapa tahapan meliputi tahap permohonan pinjaman kredit, tahap penelitian dan analisis, tahap keputusan, tahap administrasi dan tahap pencairan kredit, (2) kendala-kendala dalam sistem pengendalian intern pemberian kredit yaitu adanya karyawan yang memiliki tugas rangkap dan kurangnya sarana dan prasarana, (3) upaya yang dilakukan untuk mengatasi kendala dalam sistem pengendalian intern pemberian kredit yaitu LPD Desa Tulangnyuh sudah melakukan seleksi perekrutan karyawan pada bagian administrasi dan LPD telah menambah sarana dan prasana untuk mempermudah proses analisa dalam pemberian kredit.
\end{abstract}

Kata Kunci: sistem pengendalian internal, pemberian kredit

\begin{abstract}
This study aims to describe the internal control system of credit, obstacles encountered in implementing internal crediting system of credit, efforts to overcome the constraints in internal credit control system in LPD Tulangyuh Village Klungkung Branch. This research is a qualitative descriptive research. The subject of this research is LPD Desa Tulangnyuh Branch klungkung, While the object of this research is the internal control system of credit provision, constraints in the internal crediting system of credit and efforts to overcome the obstacle in internal control system of credit. Data were collected by interview and documentation method. The results of this study indicate that (1) the crediting system in LPD Desa Tulangnyuh Klungkung Branch through several stages include the loan loan application stage, research and analysis phase, decision stage, administration stage and credit disbursement stage. (2) obstacles in the internal control system of credit provision is the existence of employees who have double duty and lack of facilities and infrastructure. (3) the effort taken to overcome the obstacle in the internal control system of credit provision, LPD Desa Tulangnyuh has done the selection of recruitment of employees in the administration and LPD has added facilities and facilities to ease the process of analysis in lending.
\end{abstract}

Keywords: internal control system, lending

\section{PENDAHULUAN}

Negara yang berhasil dapat dilihat dari segi pembangunan terutama di bidang perekonomiannya. Perekonomian akan menjadi dasar untuk mewujudkan keberhasilan pembangunan di bidang 
lainnya. Indonesia adalah negara yang berkembang, sehingga sangat diperlukan sebuah strategi yang dapat menjadi dasar dalam pengembangan sektor pembangunannya. Keberhasilan dari pembangunan di bidang perekonomian akan tercapai apabila masyarakat mampu optimal mengembangkan usaha-usaha yang dijalankannya. Industri, Perternakan, Pertanian, Perikanan dan semua hal yang menyangkut usaha masyarakat adalah dasar untuk mengembangkan pembangunan di negeri ini, namun pada kenyataannya keterbatasan modal menjadi hambatan khususnya bagi usaha menengah. Bank menjadi sumber modal yang sangat sentral bagi para pengusaha di negeri ini, tetapi tidak semudah itu untuk mendapatkan bantuan kredit dari Bank. Maka dari itu selain dengan adanya lembaga seperti koperasi di daerah, sebagai lembaga perkreditan untuk masyarakat kelas menengah kebawah ada pula lembaga perkreditan yang bernama Lembaga Perkreditan Desa (LPD). Lembaga Perkreditan Desa adalah sebuah terobosan dari pemerintah daerah untuk menjadi sumber modal di daerah khususnya untuk masyarakat di desa.

Menurut Hasibuan (2006) kredit adalah semua jenis pinjaman yang harus dibayar kembali bersama bunganya oleh peminjam sesuai dengan perjanjian yang telah disepakati. Lebih lanjut dijelaskan menurut Thamrin (2012) istilah kredit berasal dari bahasa yunani yaitu credere yang berarti kepercayaan. Iskandar (2008) menyatakan kredit merupakan piutang bagi bank yang pelunasannya (repayment) merupakan suatu kewajiban yang harus dikembalikan debitur terhadap kewajiban utangnya, sehingga risiko kredit macet dapat dihindari. Lebih lanjut dijelaskan menurut Djumhana (2000) menyatakan kredit macet yaitu apabila tidak memenuhi kriteria lancar, kurang lancar,dan diragukan atau memenuhi kriteria diragukan, tetapi dalam jangka waktu 21 bulan sejak digolongkan diragukan belum ada pelunasan atau usaha penyelamatan kredit. Pengelolaan keuangan di LPD akan sangat dibutuhkan agar operasional dari LPD ini dapat, terus berjalan dengan terus mengatasi permasalahan-permasalahan yang akan timbul. Dalam pemberian pinjaman modal atau kredit kepada masyarakat, LPD setidaknya memiliki kriteria-kriteria yang pasti terhadap calon penerima kredit itu sendiri. Hal ini dikarenakan pemberian modal tersebut harus memiliki timbal balik yang nantinya akan dapat membantu keberlangsungan hidup LPD.

Lembaga Perkreditan Desa (LPD) merupakan salah satu aset dan sumber pendapatan desa pakraman memerlukan pengelolaan yang baik oleh pengurus dan badan pengawas. Pembentukan LPD dilatarbelakangi, oleh keterbatasan modal dan permodalan yang dimiliki oleh krama desa pakraman yang dapat menjangkau kredit-kredit yang dibutuhkan masyarakat untuk menjalankan usahanya. LPD telah mengemban fungsi untuk mendorong pembangunan ekonomi masyarakat melalui tabungan yang terarah, serta menyalurkan modal yang efektif. Disamping itu LPD juga diharapkan dapat memberantas sistem ijon dan gadai gelap yang saat ini kerap terjadi di masyarakat, fungsi lainnya juga diemban oleh LPD adalah menciptakan pemerataan dan kesempatan kerja bagi masyarakat pedesaan, baik yang biasa bekerja langsung di LPD maupun yang bisa ditampung oleh usaha -usaha produktif masyarakat yang dibiayai oleh LPD, menciptakan daya beli, serta melancarkan lalu lintas pembayaran dan pertukaran di desa juga menjadi tugas pokok LPD.

Permasalahan yang ada pada Lembaga Perkreditan Desa dalam melaksanakan kegiatan usaha untuk mencapai tujuan di bidang ekonomi adalah kurangnya SDM (Sumber Daya Manusia) atau karyawan yang masih sedikit, adanya karyawan yang memiliki tugas rangkap, dan masalah para nasabah dari LPD yang merupakan 
krama desa pakraman yang belum sepenuhnya lancar membayar cicilan kredit di LPD.

$$
\text { Menurut Ismail (2010) }
$$

menyatakan kredit macet merupakan kredit yang telah disalurkan oleh bank, dan nasabah dapat melakukan pembayaran atau melakukan angsuran sesuai dengan perjanjian yang telah ditandatangani oleh bank dan nasabah. Mudrajad Kuncoro dan Suhardjono (2002) menjelaskan bahwa kredit macet adalah suatu keadaan dimana nasabah sudah tidak sanggup membayar sebagian atau seluruh kewajibannya kepada bank seperti yang telah diperjanjikan, timbulnya kredit macet pada dunia perbankan disebabkan oleh beberapa hal diantaranya karena adanya unsur kesengajaan untuk melanggar kebijakan dan prosedur yang telah ditetapkan oleh bank.

Selain itu banyaknya persaingan dari lembaga keuangan yang lain masuk kepedesan seperti KUD (Koperasi Unit Desa) dan lain sebagainya. Dari permasalahan di atas dapat menyebabkan kineja LPD kurang efektif. Salah satu LPD yang mengalami masalah seperti ini adalah LPD Desa Pakraman Tulangnyuh Cabang Klungkung.

Kredit yang disalurkan kepada masyarakat melalui LPD perlu adanya pengendalian internal yang memadai agar terhindar dari segala bentuk penyelewengan yang mungkin terjadi, untuk itu perlu adanya sistem pengendalian internal dalam pemberian kredit. Menurut Mulyadi (2001) sistem pengendalian intern meliputi struktur organisasi, metode dan ukuran-ukuran yang dikoordinasikan untuk menjaga kekayaan organisasi, mengecek ketelitian dan keandalan data akuntansi, mendorong efisiensi dan mendorong dipatuhinya kebijakan manajemen Penanganan dan pengaturan masalah kredit benar-benar untuk memperhatikan calon nasabahnya sesuai dengan faktor yang harus diperhatikan dalam pemberian kredit
Menurut Kasmir (2001), ada beberapa prinsip-prinsip penilaian kredit yang sering dilakukan, yaitu dengan analisis 5C meliputi Character (watak), Capacity (kemampuan), Capital (modal), Collateral (jaminan), Condition of Economic (kondisi Ekonomi).

\section{Laporan Keuangan Publikasi}

LPD Desa Pakraman Tulangnyuh Cabang Klungkung, kredit yang diberikan tersebut dibedakan atas empat kategori diantaranya: kredit lancar, kredit kurang lancar, kredit diragukan dan kredit macet. Adapun besarnya kredit macet pada LPD Desa Pakraman Tulangnyuh Cabang Klungkung pada tahun 2015 kredit yang disalurkan sebesar Rp 1.349.770.000 dan kredit yang macet sebesar $R p$ 27.724.000 dengan persentase 2,05\% sedangkan pada tahun 2016 kredit yang disalurkan sebesar $\mathrm{Rp} 1.511 .000 .000$ dan kredit yang macet sebesar $R p$ 108.000.000 dengan persentase 7,14\%. Dari data tersebut maka dapat disimpulkan bahwa kredit macet dari tahun 2015 sampai tahun 2016 mengalami peningkatan. Dalam hal pemberian kredit ini pengendalian internal yang memadai sangat diperlukan oleh pihak LPD. Halim (2001) menyatakan bahwa sistem pengendalian internal adalah rangkaian proses yang dijalankan entitas, yang mana proses tersebut mencakup kebijakan prosedur sistematis, bervariasi dan memiliki tujuan utama sehingga perlu diadakan penelitian yang berjudul Analisis Pengendalian Internal Dalam Pemberian Kredit Pada Lembaga Perkreditan Desa (LPD) Desa Pakraman Tulangnyuh Cabang Klungkung.

Berdasarkan latar belakang tersebut, maka rumuskan masalah penelitian ini adalah (1) bagaimana sistem pengendalian internal pemberian kredit pada LPD Desa Tulangnyuh Cabang Klungkung? (2) kendalakendala yang dihadapi dalam melaksanakan sistem pengendalian intern pemberian kredit pada LPD Desa Pakraman Tulangnyuh Cabang Klungkung? (3) upaya apa yang diambil 
untuk menanggulangi kendala-kendala sistem pengendalian intern pemberian kredit pada LPD Desa Pakraman Tulangnyuh Cabang Klungkung?. Tujuan penelitian ini adalah (1) mendeskripsikan sistem pengendalian internal pemberian kredit pada LPD Desa Pakraman Tulangnyuh Cabang Klungkung, (2) mendeskripsikan kendala-kendala yang dihadapi dalam melaksanakan sistem pengendalian intern pemberian kredit pada LPD Desa Pakraman Tulangnyuh Cabang Klungkung, (3) mendeskripsikan upaya untuk menanggulangi kendala-kendala dalam pelaksanaaan sistem pengendalian intern pemberian kredit pada LPD Desa Pakraman Tulangnyuh Cabang Klungkung.

\section{METODE}

Adapun rancangan penelitian yang digunakan adalah penelitian deskriptif dengan pendekatan kualitatif, pada LPD Desa Pakraman Tulangnyuh Cabang klungkung. Arikunto (2001) menyatakan penelitian deskriptif kualitatif yaitu peneltian yang menggambarkan keadaan atau status fenomena yang terjadi pada suatu tempat. Jenis data yang digunakan adalah data kualitatif dan kualitatif. Data kualitatif yang diperoleh berupa informasi dalam bentuk uraian tentang sistem pengendalian intern pemberian kredit, kendala dalam melaksanakan sistem pengendalian intern, serta upaya untuk menanggulangi kendala dalam pelaksanaaan sistem pengendalian intern, sedangkan data kuantitatif data yang berupa angka-angka mengenai jumlah kredit macet yang bersumber dari LPD Desa Pakraman Tulangnyuh Cabang Klungkung. Data tersebut akan diambil dan dikumpulkan dengan metode wawancara dan dokumentasi. Wawancara dilakukan kepada Ketua LPD dan karyawan bagian kredit di LPD Desa Tulangnyuh Cabang Klungkung. Data yang telah terkumpul akan di analisis dengan menggunakan teknik analisis deskriptif kualitatif. Moleong (2007) mengemukakan bahwa metodelogi kualitatif merupakan prosedur penelitian yang menghasilkan data deskriptif berupa kata-kata tertulis maupun lisan dari orang-orang dan perilaku yang diamati. Teknik ini digunakan untuk menggambarkan keadaan LPD dan menguraikan data kualitatif mengenai sistem pengendalian intern pemberian kredit, kendala dalam melaksanakan sistem pengendalian intern, serta upaya untuk menanggulangi kendala dalam pelaksanaan sistem pengendalian intern pada LPD Desa Tulangnyuh Cabang Klungkung, sehingga dengan menguraikan data tersebut dapat ditarik kesimpulan dari permasalahan yang ada.

Subjek penelitian ini adalah LPD Desa Pakraman Tulangnyuh Cabang klungkung. Objek dari penelitian ini adalah sistem pengendalian internal pemberian kredit, kendala dalam melaksanakan sistem pengendalian intern, serta upaya untuk menanggulangi kendala dalam pelaksanaan sistem pengendalian intern pada LPD Desa Tulangnyuh Cabang Klungkung.

Teknik pengumpulan data yang digunakan dalam penelitian ini adalah Wawancara dan dokumentasi. wawancara atau interview yaitu peneliti melakukan tanya jawab atau wawancara dengan narasumber untuk mendapatkan informasi yang dibutuhkan. Wawancara yang dilakukan adalah wawancara tak berstruktur (unstructured interview). dokumentasi, peneliti menyelidiki tentang data berupa formulir pemberian kredit, dan catatancatatan tentang kredit.

$$
\text { Sugiyono }
$$

menyatakan dalam penelitian kualitatif, yang menjadi instrumen atau alat penelitian adalah peneliti itu sendiri. Penelitian kualitatif berfungsi menetapkan fokus penelitian, memilih informan sebagai sumber data, melakukan pengumpulan data, menilai kualitas data, analisis data, menafsirkan data, dan membuat kesimpulan atas temuannya. Berkaitan dengan hal itu, maka pengumpulan data data yang digunakan dalam penelitian ini adalah 
wawancara dengan menggunakan guide interview.

Pedoman wawancara guide interview instrumen penelitian yang digunakan untuk memperoleh data yang diinginkan melalui wawancara lisan. Pedoman ini berupa daftar pertanyaan yang ditanyakan kepada narasumber yaitu Direktur dan karyawan bagian kredit di LPD Desa Pakraman Tulangnyuh Cabang Klungkung. Daftar pertanyaan ini disusun sedemikian rupa dan terperinci, sehingga dapat menuntun dalam melaksanakan wawancara.

Penelitian ini disajikan dalam bentuk deskriptif yang membahas tentang sistem pengendalian intern pemberian kredit, kendala dalam melaksanakan sistem pengendalian intern, serta upaya untuk menanggulangi kendala dalam pelaksanaaan sistem pengendalian intern pada LPD Desa Tulangnyuh Cabang Klungkung.

Tahap-tahap analisis data dapat dilakukan setelah memperoleh data baik data baik dengan wawancara dan dokumentasi, kemudian data-data tersebut diolah dan dianalisis untuk mencapai tujuan akhir penelitian. Tahap-tahap analisis data dapat dilakukan dengan beberapa tahapan diantaranya: mengumpulkan data dengan analisis data, hasil pengumpulan data tersebut tentu saja perlu direduksi (data reduction), yaitu dengan mengihtisarkan hasil pengumpulan data selengkap mungkin dan memilah-milah ke dalam satuan konsep tertentu. Seperangkat hasil reduksi data juga perlu diorganisasikan kedalam suatu bentuk tertentu (display data) sehingga terlihat sosoknya secara lebih utuh, display data tersebut sangat diperlukan untuk memudahkan upaya pemaparan dan penegasan kesimpulan (conclusion).

\section{HASIL DAN PEMBAHASAN Hasil}

Berdasarkan wawancara yang telah dilakukan dengan I Wayan Ardana selaku Ketua LPD Desa Tulangnyuh
Cabang Klungkung, prosedur pengendalian internal pemberian kredit pada LPD Desa Tulangnyuh Cabang Klungkung dapat dilihat sebagai berikut (1) tahap permohonan pinjaman kredit, pada tahap ini diawali dengan kedatangan calon nasabah ke bagian kredit (Ni Nyoman Suastini) untuk meminta formulir permohonan pinjaman kredit (modal kerja atau kredit konsumtif) dan diisi sesuai dengan syarat-syarat yang telah ditentukan. Calon nasabah mengajukan secara tertulis dalam blanko permohonan yang dikeluarkan oleh LPD dan harus dilengkapi oleh pemohon kredit (calon nasabah) berupa (1) identitas diri calon nasabah, (2) permohonan baru, tambahan, perpanjangan dan penurunan, (3) nomer Tabungan, (4) jumlah kredit yang dimohon, (5) suku bunga, (6) tujuan penggunaan kredit, (7) jangka waktu, (8) kesanggupan membayar, administrasi, bea materai, (9) kesanggupan untuk menabung, (10) tanda tangan pemohon, (11) tanda tangan penanggung. Didalam data-data yang disajikan diatas dapat dirangkum pada blanko permohonan kredit. Pada tahap ini permohonan kredit akan ditangani oleh bagian kredit (Ni Nyoman Suastini) di LPD Desa Tulangnyuh, yang nantinya akan ditulis pada buku registrasi permohonan kredit masuk. Selanjutnya syarat-syarat yang harus dipenuhi oleh calon nasabah adalah sebagai berikut. (a) Kredit Modal Kerja pada LPD, untuk fasilitas kredit modal kerja yang di peruntukkan bagi calon nasabah yang akan digunakan untuk tambahan modal usaha dagang, diamana kredit ini merupakan jenis kredit dengan sistem bunga menurun dan jumlah plafon kredit disesuaikan dengan nilai jaminan atau agunan dan juga kemampuan bayar dari calon nasabah, produk ini memiliki jangka waktu 10 tahun. Dimana dalam pengajuan permohonan ini nantinya perlu disertakan berupa (1) fotokopi Kartu Tanda Penduduk (KTP) suami, isteri rangkap dua, (2) fotokopi Kartu Keluarga (KK), (3) fotokopi Buku Pemilik Kendaraan Bermotor (BPKB) 
dan Surat Tanda Nomor Kendaraan (STNK) untuk jaminan sepeda motor dan mobil, fotokopi sertifikat, (4) Surat Izin Usaha Perdagangan (SIUP) dan (5) Nomer Pokok Wajib Pajak (NPWP). (b) Kredit Konsumtif, merupakan jenis kredit yang diperuntukkan sebagai pembelian tanah, rumah, kendaraan dan barang lainnya dimana jangka waktu kredit sampai 10 tahun dengan sistem bunga menurun. Kredit konsumtif menggunakan jaminan baik berupa kendaraan dan sertifikat dimana dalam pengajuan permohonan ini nantinya perlu disertakan berupa (1) fotokopi Kartu Tanda Penduduk (KTP) suami, isteri rangkap dua, (2) fotokopi Kartu Keluarga (KK), (3) fotokopi Buku Pemilik Kendaraan Bermotor (BPKB) dan Surat Tanda Nomor Kendaraan (STNK) untuk jaminan sepeda motor dan mobil, fotokopi sertifikat, dan (4) Nomer Pokok Wajib Pajak (NPWP). Setelah semua syarat-syarat terpenuhi maka calon nasabah dapat mengajukan formulir surat permohonan pinjaman kepada bagian kredit (Ni Nyoman Suastini) dan selanjutnya akan dianalisa. 2) Tahap penelitian dan analisam, pada tahap ini bagian kredit (Ni Nyoman Suastini) akan menganalisis permohonan kredit dari segala aspek keuangan maupun non keuangan yang meliputi aspek $5 \mathrm{C}$ dan juga informasi mengenai riwayat kredit calon nasabah di lembaga keuangan lainnya atau Sistem Informasi Debitur (SID) apakah calon nasabah yang bersangkutan lancar atau tidak lancar dalam masalah pembayaran kredit di lembaga keuangan lainnya yang nantinya akan dipakai suatu pertimbangan mengenai diterima atau ditolaknya permohonan kredit calon nasabah. Apabila pada tahap ini calon nasabah sudah memenuhi kriteria untuk bisa diberi kredit, maka bagian kredit ( $\mathrm{Ni}$ Nyoman Suastini) akan menyerahkan hasil analisis permohonan kredit tersebut kepada ketua LPD (I Wayan Ardana). (3) Tahap keputusan, pada tahap keputusan, hasil analisis permohonan kredit telah diterima oleh ketua LPD (I Wayan Ardana).
Selanjutnya, I Wayan Ardana akan memberikan keputusan apakah permohonan kredit disetujui atau ditolak. Apabila disetujui oleh ketua LPD (I Wayan Ardana) maka bagian kredit (Ni Nyoman Suastini) akan membuat surat perjanjian pinjaman, surat keputusan, surat jaminan dan prima nota/blanko kredit masing-masing rangkap dua, satu untuk bagian kredit (Ni Nyoman Suastini) dan yang satu untuk calon nasabah. Apabila nantinya dalam penentuan keputusan ini ada calon nasabah yang ditolak permohonan kreditnya karena nilai jaminan kurang mendukung atau kemampuan bayar calaon nasabah tidak ada, maka bagian kredit $(\mathrm{Ni}$ Nyoman Suastini) akan menyampaikan kepada calon nasabah baik melalui surat atau telepon. (4) Tahap Administrasi, setelah di putuskan dan disetujui permohonan kredit calon nasabah oleh Ketua LPD Desa Tulangnyuh (I Wayan Ardana) maka kredit bisa di realisasi. Bagian administrasi (Ni Kadek Puspitawati) akan memproses kredit tersebut sesuai dengan apa yang telah menjadi keputusan dari Ketua LPD (I Wayan Ardana) baik mengenai nominal pinjaman kredit, jangka waktu, suku bunga, biaya-biaya yang timbul, jaminan dan jumlah angsuran kredit. Maka perjanjian kredit bisa dibuatkan yang nantinya akan di tandatangani oleh calon nasabah. Sebelum dilakukan penandatanganan perjanjian kredit calon nasabah akan diminta menunjukkan dokumen asli dari permohonan kredit seperti dokumen asli jaminan berupa surat tanah atau suratsurat kendaraan bermotor. Setelah dokumen lengkap dan sudah ditandatangani maka proses kredit akan dilanjutkan pada tahap pencairan kredit. (5) Tahap Pencairan Kredit, LPD Desa Tulangnyuh Cabang Klungkung akan menyetujui pencairan kredit apabila syarat-syarat yang harus dipenuhi oleh calon nasabah telah dilaksanakan. Penandatanganan pinjaman kredit harus telah selesai sebelum pencairan kredit, yang bertanggung jawab pada 
tahap ini pencairan kredit adalah Teller (I Ketut Wiriasa) di LPD Desa Tulangnyuh. Pencairan kredit ini bisa berupa pembayaran secara tunai dan pemindahbukuan pada rekening tabungan nasabah.

Kendala-kendala dalam

melaksanakan sistem pengendalian intern pemberian kredit pada LPD Desa Pakraman Tulangnyuh Cabang Klungkung. Berdasarkan hasil wawancara yang telah dilakukan dengan I Wayan Ardana selaku ketua LPD Desa Tulangnyuh Cabang Klungkung, kendala-kendala yang dihadapi dalam melaksanakan sistem pengendalian intern pemberian kredit pada LPD Desa Tulangnyuh Cabang Klungkung adalah sebagai berikut (1) adanya karyawan yang memiliki tugas rangkap, karyawan di LPD Desa Tulangnyuh Cabang Klungkung terlalu belum memadai yang hanya berjumlah 3 (tiga) orang yaitu Ni Nyoman Suastini, I Ketut Wiriasa dan Ni Kadek Puspita Wati. Pada LPD Desa Tulangnyuh ada karyawan yang masih merangkap tugasnya, seperti bagian kredit (Ni Nyoman Suastini) terkadang harus mengerjakan tugas sebagai administrasi. Hal ini menyebabkan dalam menyelesaikan tugas membutuhkan waktu lama dan kadangkadang karyawan akan merasa kesulitan untuk menentukan skala prioritas apabila dua atau lebih pekerjaan yang memerlukan penyelesaian pada waktu yang bersamaan. (2) kurangnya sarana dan prasarana. Pada LPD Desa Tulangnyuh sarana dan prasarana seperti komputer, dan alat teknologi lainnya masih kurang memadai hanya ada 2 (dua) komputer yang dimiliki desa Tulangnyuh. Hal ini akan menghambat proses kinerja LPD khususnya dalam menganalisa kredit.

Upaya untuk mengatasi kendala-kendala sistem pengendalian intern pemberian kredit pada LPD Desa Pakraman Tulangnyuh Cabang Klungkung. Berdasarkan hasil wawancara dengan Ketua LPD Desa Tulangnyuh (I Wayan Ardana), struktur organisasi yang dimiliki oleh LPD Desa
Tulangnyuh Cabang Klungkung sudah cukup baik. Jika dalam suatu sistem pengendalian intern pemberian kredit terdapat masalah kendala-kendala maka upaya yang dilakukan oleh LPD Desa Tulangnyuh Cabang Klungkung adalah sebagai berikut (1) LPD sudah melakukan seleksi perekrutan karyawan dengan menambah 2 (dua) orang karyawan pada bagian administrasi, karena karyawan di LPD masih sedikit jumlahnya yaitu hanya 3 (tiga) orang yaitu Ni Nyoman Suastini, I Ketut Wiriasa dan Ni Kadek Puspita Wati, hal ini dilakukan untuk menghindari adanya karyawan yang memiliki tugas rangkap dan mempermudah proses pemberian kredit pada LPD Desa Tulangnyuh Cabang Klungkung. (2) LPD Desa Tulangnyuh membutuhkan 3 (tiga) komputer lagi untuk mempermudah proses analisa kredit, akan tetapi LPD telah membeli satu unit komputer dan satu unit printer untuk menambah sarana dan prasarana, karena dana yang dimiliki LPD sedikit.

\section{Pembahasan}

Sistem Pengendalian Intern Pemberian Kredit pada LPD Desa Tulangnyuh Cabang Klungkung. Dari hasil wawancara dengan ketua LPD Desa Tulangnyuh Cabang Klungkung, dapat dilihat bahwa sistem pemberian kredit yang dilaksanakan oleh LPD Desa Tulangnyuh Cabang Klungkung sudah memadai, terbukti dengan dilaksanakannya tahapan pemberian kredit sebagai berikut (1) tahap permohonan pinjaman kredit, (2) tahap penelitian dan analisis, (3) tahap keputusan, (4) tahap administrasi, dan (5) tahap pencairan kredit. Penelitian ini sejalan dengan teori Kasmir (2011) yang menyatakan bahwa prosedur pemberian kredit adalah sebagai berikut (1) pengajuan berkas-berkas, penyelidikan berkas pinjaman, wawancara, (4) on the spot, (5) keputusan kredit, (6) penandatanganan akad kredit, (7) realisasi kredit, dan (8) pencairan dana.

dalam $\begin{gathered}\text { Kendala-kendala yang } \\ \text { melaksanakan }\end{gathered} \begin{gathered}\text { dihadapi } \\ \text { sistem }\end{gathered}$ 
pengendalian intern pada LPD Desa Tulangnyuh Cabang Klungkung adalah dalam penerapan sistem pemberian kredit tentu akan ada kendala-kendala yang dihadapi, adapun kendala-kendala yang dihadapi oleh LPD Desa Tulangnyuh Cabang Klungkung dalam penerapan sistem pengendalian intern pemberian kredit yaitu, adanya karyawan yang memiliki tugas rangkap, dan kurangnya sarana dan prasarana yang dimiliki oleh LPD Desa Tulangnyuh.

Penelitian ini sejalan dengan penelitian yang dilakukan Lukieto Cahyadi (2014) dengan hasil penelitian menyatakan bahwa Berdasarkan analisa, sistem dan prosedur pemberian kredit yang diberikan oleh pihak PT. BPR NBP 18 Cabang Tebing Tinggi masih terdapat beberapa hal yang kurang sesuai yaitu adanya beberapa pada staf bagian tertentu yang belum terisi yang disebabkan karena kurangnya personel/karyawan, sehingga dapat terjadi penyalahgunaan wewenang, serta belum adanya (Surprised Auditor) pemeriksaan mendadak untuk memeriksa semua data-data yang dibuat oleh karyawan sesuai tugas dan tanggung jawabnya yang bertujuan agar setiap karyawan melaksanakan tugasnya dengan baik dan telah siap apabila sewaktu-waktu ada pemeriksaan mendadak. Dalam upaya meningkatkan pengendalian kredit pada PT. BPR NBP 18 Cabang Tebing Tinggi yang mengacu pada aspek-aspek pengendalian kredit, dilakukan: 1) Personal yang kompeten dan dapat dipercaya, 2) Pemisahan tugas yang memadai, 3) Prosedur otorisasi yang tepat, 4) Dokumen dan catatan yang memadai, 5) Kontrol fisik aktiva dan catatan, dan 6) Pemeriksaan pekerjaan secara independen.

Upaya untuk menanggulangi kendala-kendala sistem pengendalian intern pemberian kredit pada LPD Desa Pakraman Tulangnyuh Cabang Klungkung. Upaya yang dilakukan LPD Desa Tulangnyuh dalam menanggulangi sistem pengendalian intern pemberian kredit, jika dalam suatu sistem pengendalian intern pemberian kredit terdapat kendala yang dialami oleh LPD Desa Tulangnyuh Cabang Klungkung pasti ada upaya yang dilakukan untuk mengatasi kendala-kendala tersebut. Jika dalam suatu sistem pengendalian intern pemberian kredit terdapat masalah, maka upaya yang dilakukan oleh LPD Desa Tulangnyuh Cabang Klungkung adalah sebagai berikut (1) LPD sudah melakukan seleksi perekrutan karyawan dengan menambah 2 (dua) orang karyawan pada bagian administrasi, karena karyawan di LPD masih sedikit jumlahnya yaitu hanya 3 (tiga) orang yaitu Ni Nyoman Suastini, I Ketut Wiriasa dan Ni Kadek Puspita Wati, hal ini dilakukan untuk menghindari adanya karyawan yang memiliki tugas rangkap dan mempermudah proses pemberian kredit pada LPD Desa Tulangnyuh Cabang Klungkung. (2) LPD Desa Tulangnyuh membutuhkan 3 (tiga) komputer lagi untuk mempermudah proses analisa kredit, akan tetapi LPD telah membeli satu unit komputer dan satu unit printer untuk menambah sarana dan prasarana, karena dana yang dimiliki LPD sedikit.

\section{SIMPULAN DAN SARAN Simpulan}

Berdasarkan analisis yang telah dilakukan dengan menggunakan metode deskriptif dengan pendekatan kualitatif terhadap sistem pengendalian internal pemberian kredit pada LPD Desa Tulangnyuh Klungkung, maka dapat ditarik simpulan bahwa

Sistem pemberian kredit pada LPD Desa Tulangnyuh Cabang Klungkung melalui beberapa tahapan yaitu 1) Tahap permohonan pinjaman kredit, tahap ini diawali dengan kedatangan calon nasabah ke bagian kredit (Ni Nyoman Suastini) untuk meminta formulir permohonan pinjaman kredit (modal kerja atau kredit konsumtif) dan diisi sesuai dengan syarat-syarat yang telah ditentukan. 2) tahap penelitian dan analisis, Pada tahap ini bagian kredit (Ni Nyoman Suastini) akan menganalisis 
permohonan kredit dari segala aspek keuangan maupun non keuangan yang meliputi aspek $5 \mathrm{C}$ dan juga informasi mengenai riwayat kredit calon nasabah di lembaga keuangan lainnya, 3) tahap keputusan, pada tahap keputusan hasil analisis permohonan kredit telah diterima oleh ketua LPD (I Wayan Ardana), selanjutnya I Wayan Ardana akan memberikan keputusan apakah permohonan kredit disetujui atau ditolak. (4) tahap administrasi, Setelah di putuskan dan disetujui permohonan kredit calon nasabah oleh Ketua LPD Desa Tulangnyuh (I Wayan Ardana) maka kredit bisa di realisasi. Bagian administrasi (Ni Kadek Puspitawati) akan memproses kredit tersebut sesuai dengan apa yang telah menjadi keputusan dari Ketua LPD ( I Wayan Ardana), 5) tahap pencairan Kredit, LPD Desa Tulangnyuh Cabang Klungkung akan menyetujui pencairan kredit apabila syarat-syarat yang harus dipenuhi oleh calon nasabah telah dilaksanakan.

dalam $\begin{gathered}\text { Kendala-kendala yang dihadapi } \\ \text { melaksanakan sistem }\end{gathered}$
pengendalian intern pemberian kredit pada LPD Desa Tulangnyuh Cabang Klungkung adalah sebagai berikut (1) adanya karyawan yang memiliki tugas rangkap, pada LPD Desa Tulangnyuh ada karyawan yang masih merangkap tugasnya, seperti bagian kredit (Ni Nyoman Suastini) terkadang harus mengerjakan tugas sebagai administrasi. Hal ini menyebabkan dalam menyelesaikan tugas membutuhkan waktu lama. 2) Kurangnya sarana dan prasarana, pada LPD Desa Tulangnyuh sarana dan prasarana seperti komputer, dan alat teknologi lainnya masih kurang memadai.

Upaya yang dilakukan oleh LPD Desa Tulangnyuh Cabang Klungkung dalam menanggulangi kendala-kendala sistem pengendalian intern pemberian kredit adalah sebagai berikut 1) LPD sudah melakukan seleksi perekrutan karyawan dengan menambah 2 (dua) orang karyawan pada bagian administrasi, karena karyawan di LPD masih sedikit jumlahnya yaitu hanya 3 orang yaitu $\mathrm{Ni}$ Nyoman Suastini, I Ketut Wiriasa dan $\mathrm{Ni}$ Kadek Puspita Wati, 2) LPD Desa Tulangnyuh telah membeli satu unit komputer dan satu unit printer untuk menambah sarana dan prasarana, sehingga mempermudah proses analisa dalam pemberian kedit di LPD.

\section{Saran}

Berdasarkan simpulan hasil penelitian dan pembahasan tersebut, maka saran yang dapat dijadikan masukan dalam pelaksanaan sistem pengendalian internal pemberian kredit pada LPD Desa Tulangnyuh Cabang Klungkung sebagai berikut (1) untuk memenuhi kriteria sistem pengendalian intern pemberian kredit yang memadai diharapkan LPD Desa Tulangnyuh Cabang Klungkung menambah sarana dan prasarana agar mempermudah proses analisa dalam pemberian kredit kepada nasabah. (2) Bagi peneliti selanjutnya diharapkan agar lebih memperbanyak sumber data perbankan yang diteliti agar mempermudah dalam memahami sistem pengendalian intern pemberian kredit dengan teori yang ada.

\section{DAFT AR PUSTAKA}

Arikunto, Suharsimi 2001. Prosedur penelitian: Suatu

Pendekatan Praktek. Edisi

Revisi V. Cetakan

keduabelas. Jakarta :Rineka

Cipta

Djumhana, Muhammad, 2000. Hukum Perbankan di Indonesia,

Bandung: PT Citra Aditya Bakti

Abdul Halim. 2001. Akuntansi Keuangan Daerah. Jakarta: Salemba Empat

Hasibuan, Malayu S.P. 2006. DasarDasar Perbankan. Jakarta: Erlangga

Iskandar, Syamsu. 2008. Bank dan Lembaga Keuangan Lain. Jakarta:PT Semesta Asa Bersama. 
Ismail. 2010. Manajemen Perbankan: Dari Teori Menuju Aplikasi. Jakarta: Prenada Media Group.

Kasmir. 2001. Bank dan Lembaga Keuangan Lainnya. Jakarta: PT. Raja Grafindo.

Meleong, Lexy. 2007. Metodelogi Penelitian Kualitatif. Bandung: PT Remaja Rosda Karya.

Mudrajat, Kuncoro dan Suhardjono. 2002, Manajemen Perbankan Teori dan Aplikasi, Yogyakarta: BPFE

Mulyadi. 2001. Sistem Akuntansi, Edisi Ketiga, Cetakan Ketiga, Penerbit

Salemba Empat, Jakarta. Sugiyono.

2012. Memahami Penelitian Kualitatif. Alfabeta.

Bandung:

Thamrin, Abdullah. 2012. Manajemen Pemasaran. Jakarta:PT Raja Grafindo Persada. 